\title{
Planting date effects on maize (Zea mays L.) growth and development in the rainforest of southwestern Nigeria
}

\author{
Chris Adegoke FAYOSE ${ }^{1}$ and Morakinyo Abiodun Bamidele FAKOREDE ${ }^{1,2}$
}

Received October 05, 2019; accepted January 18, 2021. Delo je prispelo 05. oktobra 2019, sprejeto 18. januarja 2021.

Planting date effects on maize (Zea mays L.) growth and development in the rainforest of southwestern Nigeria

Abstract: This study was conducted to determine the optimum planting date for maize (Zea mays L.) to cope with the negative impacts of climate change in the marginal rainforest agro-ecology as typified at Ile-Ife, SW Nigeria. Five maize varieties were planted weekly, in 3-replicate randomized complete block design experiments at the Obafemi Awolowo University Teaching and Research Farm, throughout the 2016 and 2017 cropping seasons. The varieties were monitored for seedling and adult plant traits including grain yield with its components. Statistical analysis showed significant effect of planting dates (DOP) on all traits. The first few DOPs in March and April had the highest grain yield which reduced with delayed planting till June and increased again mid July/August before finally dropping off thereafter. The higher yield in the earlier dates each year, was due to early flowering and taller plants with higher ear placement. Planting after the first few rains in March/April was the optimum for the first cropping season, and late July to mid-August was best for the second cropping season in this agroclimatic zone. Planting beyond these periods results in poor grain yield and pre-disposes the crop to terminal drought, which could result in complete crop failure.

Key words: agronomy; climate change impact and adaptation; drought; Zea mays L.
Vplivi datuma setve na rast in razvoj koruze (Zea mays L.) v območjih deževnega gozda jugozahodne Nigerije

Izvleček: Raziskava je je bila izvedena za določitev optimalnih datumov setve koruze (Zea mays L.) za spoprijemanje z negativnimi posledicami podnebnih sprememb na mejnih območjih deževnega gozda v Ile-Ife, jugozahodna Nigerija. Pet sort koruze je bilo posejanih tedensko v popolnem naključnem bločnem poskusu s tremi ponovitvami na raziskovalnem posetvu Obafemi Awolowo University Teaching, v rastnih sezonah 2016 in 2017. Pri vseh sortah so bile spremljane lastnosti rastlin od sejank do odraslih rastlin, vključno s pridelkom in njegovimi komponentami. Statistična analiza je pokazala značilen vpliv datuma setve (DOP) pri vseh lastnostih. Prvi datumi setve $\mathrm{v}$ marcu in aprilu so imeli največji pridelek zrnja, ki se je nato zmanjševal do setve $\mathrm{v}$ juniju in spet povečeval do setve $\mathrm{v}$ sredini julija in avgusta, nakar je končno upadel. Večji pridelek pri zgodnejših datumih setve je bil vsako leto povezan z zgodnejšim cvetenjem, višjimi rastlinami in z višjim položajem storžev. Setev po prvih deževjih v marcu in aprilu je bila optimalna za prvi del rastne sezone, setev koncem julija do sredine avgusta pa je bila najboljša za drugi del rastne sezone v teh agroekoloških razmerah. Setve izven teh obdobij do dale majhen pridelek zrnja zaradi izpostavljenosti suši, kar bi lahko vodilo k popolni izgubi letine.

Ključne besede: agronomija; vpliv podnebnih sprememb in prilagoditve; suša; Zea mays L. 


\section{INTRODUCTION}

Maize (Zea mays L.) is a popular crop in sub-Saharan Africa (SSA) and its popularity in the region has continued to grow because it provides a cheap source of calories for the relatively poor population, who process it to different food forms in addition to consuming it boiled or roasted. A good number of industries, including the livestock industries also depend on maize for the production of feed and other products as a result of which the demand for the grains remains high (Talabi et al., 2017). Unfortunately, in Nigeria today, there is a considerable reduction in the area of land available for agricultural production due to increased urbanization. There is also continous decline in soil fertility, resulting from persistent cultivation of a piece of land over several or many years. Furthermore, there is the impact of climate change which shows as poor condtions of climate, including drought, and a reduction in the effective growing season due to delayed onset of rainfall followed by early rainfall recession (Fakorede and Akinyemiju, 2003). These are key factors limiting maize production from keeping up with the high demands for its grains.

In Nigeria as in many other countries of the world, maize has received relatively large research attention from agronomists, plant breeders and other crop scientists over the years. Genetic improvement has been made on many important aspects of the crop, including the development of high yielding, disease resistant, drought tolerant and nutritionally fortified varieties (Badu-Apraku and Fakorede, 2017). However, yield could be further enhanced with improved cultural practices, including optimum planting dates. Studies have shown that planting maize outside its optimum dates of planting results in reduced yield (Fakorede, 1985). Investigations had started since the late 1970s at the Obafemi Awolowo University (formerly University of Ife), Ile-Ife to determine the optimum planting dates for maize in the marginal rainforest agro-ecology of Ile-Ife in Southwestern Nigeria. Fakorede (1985) found at Ile-Ife that yield decreased by 30,38 and $34 \mathrm{~kg} \mathrm{ha}^{-1}$ for each day by which sowing was delayed after the first planting in March of 1978, 1980 and 1981 respectively. He suggested early planting of maize with the first few rains in the year to ensure optimum yield. Oluwaranti et al. (2008) evaluated the yield performance of different maturity groups of maize varieties at different planting dates (DOP) at the same location and found that grain yield and yield components decreased with delayed planting in the late season. Planting date studies in the savanna regions of Nigeria have shown similar results. In the Sudan savanna zone, for example, Jibrin et al. (2012) found late June to early July as the optimum planting window for maize; grain yield decreases drastically with delayed planting beyond this period.

Rainfall is the primary climatic factor that determines the timing of most agronomic practices, especially planting operations in Nigeria. False start of rainfall and unpredictable frequent occurrence of short duration drought during the growing season, both of which have become more severe over time, are now features of the rainforest agro-climatic zone of SW Nigeria typified by Ile-Ife, a location at $7^{\circ} 28^{\prime} \mathrm{N}, 4^{\circ} 33^{\prime} \mathrm{E}$ and $244 \mathrm{~m}$ asl in the zone. Such weather anomalies have been attributed to climate change (Fakorede and Akinyemiju, 2003). Reduced seedling emergence and low vigor, culminating in missing stands, are usually associated with the weather anomalies that characterize early planted maize in the zone. Despite these negative impacts, early planted maize under research as well as farmer practices produce higher yields than plantings delayed till when the environments are seemingly more favorable. Based on this observation, Fakorede (1985) hypothesized that cultivars for early planting would be more productive if they emerged rapidly, with high seedling and vegetative vigor under relatively hot, dry conditions. Furthermore, most of the DOP studies thus far in Nigeria involved open-pollinated varieties (OPVs), although Fakorede's (1985) study included some varietal hybrids, a type of hybrid that has never been commercialized in Nigeria. The varieties were also not screened for drought and or heat tolerance. However, drought and or heat tolerant OPVs belonging to different maturity groups (extra early, early, intermediate, late), as well as conventional types of hybrid (single-cross, double-cross, 3-way cross hybrids) also of different maturity groups, are now available and are cultivated by farmers in Nigeria. In addition, most DOP studies conducted so far in the rainforest agroclimatic zone of Nigeria involved relatively few dates within each planting season. The study by Oluwaranti et al. (2008) which was conducted during a 4-year period, showed contrasting trends in the early season, a clear indication of the need for more investigations. Studies conducted in advanced countries, such as that by Jong et al. (1982) inter alia suggested that the larger the sampling size of the environment, the more reliable the results obtained for purposes of prediction and recommendation of agronomic practices.

The primary objective of the present study, therefore, was to further investigate the trends in growth, grain yield and yield components of maize planted at weekly interval, starting with the first few rains in March till the recession of rainfall in November for a 2-year period. A secondary objective was to investigate the presence of genotype $\mathrm{x}$ DOP interaction with the goal of recommending varietal types adapted to specific planting periods in the agroclimatic zone. 


\section{MATERIALS AND METHODS}

The study was carried out at the Teaching and Research Farm of Obafemi Awolowo University, Ile-Ife (OAU T\&R Farm) in years 2016 and 2017. In each experiment, five maize varieties (four OPVs and one single-cross hybrid), well adapted to the tropical rainforest environments, were planted in 3-replicate randomized complete block design. The OPVs included 'White DT STR SYN1 - TZL Comp. 1-W', 'TZL Comp. 4 DT F', 'TZL Comp. 1 C6/DT - SYN - 1 - W' all of which were drought tolerant (DT) and of intermediate/late maturity, 'ACR 94 TZE Comp $5 \mathrm{C}_{3}$ ' (early maturing), and 'Oba Super 1', an intermediate-late single-cross hybrid obtained from Premier Seeds, Zaria. The four OPVs were obtained from the IITA Maize Improvement Program, and all five varieties are white-grained, high yielding and have been released for commercial production in Nigeria and several other West and Central African (WCA) countries.

The experiments were planted weekly from March to November each year. Each planting date (DOP) represented the individual environment. However, there were some weeks when planting could not be done due to some logistic problems, but 56 plantings (28 each year) were effected, out of which 54 (data unavailable to calculate emergence parameters for the first DOP in March each year due to rainfall anomalies) were analysed for seedling emergence and vigour. Only 42 DOPs (20 in 2016 and 22 in 2017) attained maturity and were analyzed for flowering, plant and ear heights, and grain yield. Each plot contained six or four rows which were $5 \mathrm{~m}$ long and $0.75 \mathrm{~m}$ apart; within row spacing was $0.5 \mathrm{~m}$ resulting in plot size of about $15 \mathrm{~m}^{2}$ and $22.5 \mathrm{~m}^{2}$ for the four and six-row plots. Prior to planting, the experimental land was ploughed and harrowed and seeds were treated with Apron ${ }^{*}$ which contains thiamethoxam, mefenoxam (metalaxyl-M) and difenoconazole, to control damage by soil-borne diseases and insect pests. Three seeds were planted per hill and thinning was done at 9 days after planting (DAP) to two plants per stand giving an estimated plant population density of 53, 333 plants ha ${ }^{-1}$. Fertilizer was applied immediately after thinning at the rate of $60 \mathrm{~kg} \mathrm{ha}^{-1}$ each for $\mathrm{N}, \mathrm{P}_{2} \mathrm{O}_{5}$ and $\mathrm{K}_{2} \mathrm{O}$. Primextra, which contains atrazine (2-chloro-4- (ethyl amino)-6-isopropylamino-s-triazine) and alachlor (N-(methyl-2-methoxy-ethyl)-2-ethyl8-methyl-chloroacetanilide) as active ingredients was applied as post-planting, maize pre-emergence herbicide at the rate of $5 \mathrm{l} \mathrm{ha}^{-1}$. Further weed control was done using paraquat ( $\mathrm{N}, \mathrm{N}^{\prime}$-dimethyl-4,4'-bipyridinium dichloride), carefully applied as a post-emergence, non-selective and contact herbicide at the rate of $3.0 \mathrm{l} \mathrm{ha}^{-1}$.

Emergence counts were made daily from five to nine days after planting (DAP); from which emergence percentage $(E \%)$ and emergence index $(E I)$ were computed as follows (Fakorede and Agbana (1983):

$$
\begin{aligned}
& E \%=\frac{\text { Seedlings emerged in } X D A P}{\text { Total no. of seeds sown }} * 100 \\
& E I=\frac{\sum(\text { Plants emerged in a day }) *(D A P)}{\text { Plants emerged } 9 D A P}
\end{aligned}
$$

The dates of the appearance of the first flower (tassel) and number of days to $50 \%$ tasselling, anthesis (pollen shed) and incipient silk extrusion were recorded for each plot in both years. Plant and ear heights (PHT and EHT) were obtained by measuring the distance from the soil surface to the first branch at the base of the tassel, and the node bearing the top ear for 10 random plants in each plot and their means taken as PHT and EHT per plot, respectively. Data were collected on grain yield and yield components (ear number and mass, ear length and kernel moisture content). The grain yield data were adjusted to $15 \%$ moisture content. Variance analysis was done on all data using PROC GLM of Statistical Analysis System (SAS, 2000). The linear additive model for the ANOVA was: $Y_{i j k}=\mu+\alpha_{i}+\beta_{j(i)}+\Sigma_{k}+\alpha \Sigma_{(i k)}+\Sigma_{i j k}$ in which $Y_{i j k}$ is the observed measurement of the $k^{\text {th }}$ genotype grown in the $j^{\text {th }}$ rep under the $i^{\text {th }}$ environment; $\mu$ is the grand mean; $\alpha_{i}$ is the main effect of the $i^{\text {th }}$ environment, $\mathrm{i}=1,2, \ldots . ., 42$ or $54 ; \beta_{j(i)}$ is the effect of the $j^{\text {th }}$ replication nested within the $i^{\text {th }}$ environment, $j=1,2,3 ; \Sigma_{k}$ is the effect of the $k^{\text {th }}$ genotype, $\mathrm{k}=1,2, \ldots .5 ; \alpha \Sigma_{(i k)}$ is the first order interaction of the $i^{\text {th }}$ environment with the $k^{\text {th }}$ genotype, and $\Sigma_{i j k}$ is the random error (residual) term. Furthermore, correlation and regression analyses were done for all data to determine the trends in response of maize to planting dates. The measured traits (emergence, flowering, PHT, EHT and yield) were regressed on DOP in linear model: $Y=$ $a+b X$ and polynomial model: $Y=a+b 1 X^{1}+\ldots b n X^{n}$, $Y$ and $\mathrm{X}$ are the measured traits and DOP, respectively; $\mathrm{a}$ and $\mathrm{b}$ are the intercept and slope/coefficient of the regression, respectively; $\mathrm{n}$ is the order of the polynomial (quadratic, cubic, quartic). Pearson correlation analysis was done where the coefficient.

$$
\mathbf{r}=\frac{\Sigma(\boldsymbol{X}-\overline{\mathbf{x}})(\mathbf{Y}-\bar{Y})}{\sqrt{[\Sigma(X-\overline{\mathbf{x}}) 2 * \Sigma(\boldsymbol{Y}-\bar{Y}) 2]}} .
$$

\section{RESULTS}

Results from the variance analysis revealed highly significant DOP effect for all traits (Table 1). Emergence, adult plant traits and grain yield along with its components were highly significant $(p \leq 0.01)$ for DOP and other sources of variation.Fairly high emergence for the 


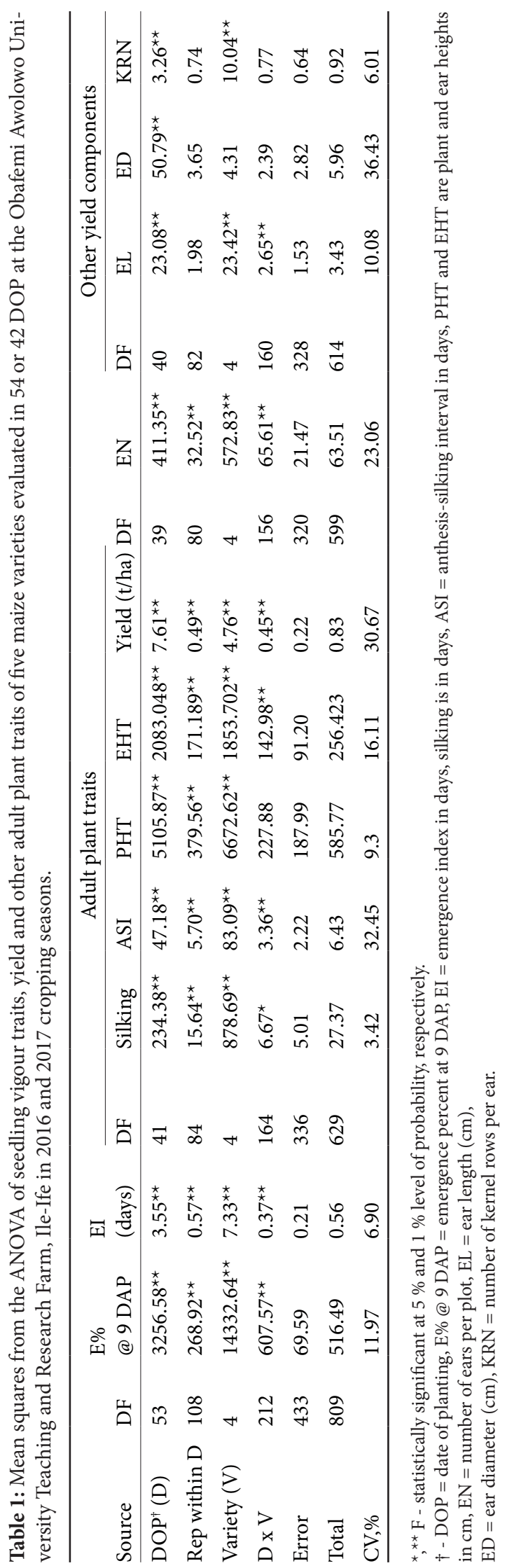




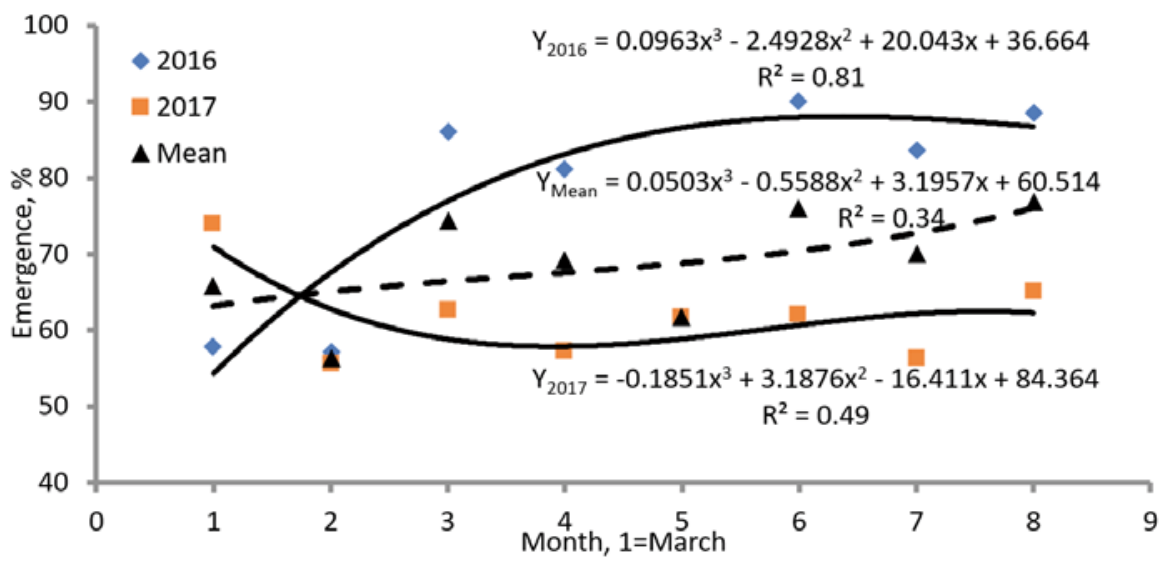

Figure 1: Mean values by months for emergence percentage (\%) at 9 DAP of five maize varieties evaluated in 54 environments at the OAU T\&R Farm in 2016 and 2017 seasons.

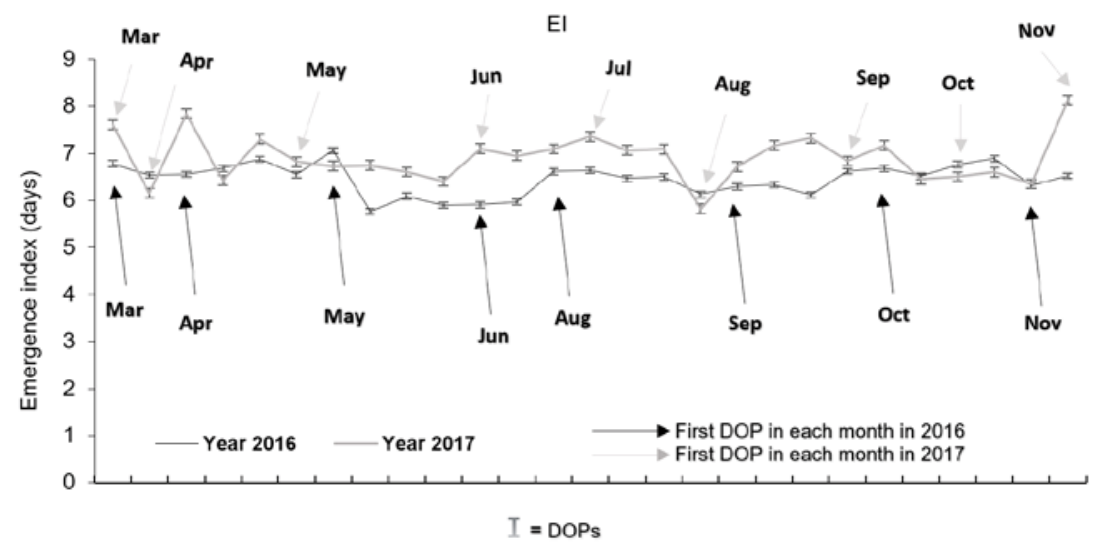

Figure 2: Mean values for the emergence index (in days) of five maize varieties evaluated in 54 environments at the OAU T\&R Farm in 2016 and 2017 seasons.

first DOPs in March each year was followed by a period of low emergence in late March/April (Figure 1). Thereafter emergence increased steadily on the average from May and was fairly uniform mid-season when rainfall is expected to be high, until around October when it decreased steadily, even though the $\mathrm{R}^{2}$ value (34\%) was quite low despite the high $\mathrm{R}^{2}$ value $(81 \%)$ observed in 2016. Emergence was generally higher and faster in 2016 than 2017 with an opposite trend between the years for EI (Figures 1 and 2).

There was really no definite pattern for silking with respect to DOP over the two years, except for the earliness in silking observed in the first couple of environments in 2016. Similar trends occurred for tasseling and anthesis. The interval between anthesis and silking, ASI, showed a similar trend to the other flowering traits, but for a wider margin where differences occurred between the two years (Figure 3).

Plant and ear heights generally showed a trend where they appeared to be fairly uniform mid-seasons, although planting very early or at the latter part of the season produced contrasting results. However, plants were taller and ears placed higher in most dates in 2016 (Figure 4).

Grain yield was highest for the first few DOPs in March and April (Figures 5 and 6) even though other environments planted later in March and April each year had some of the poorest yield performances compared to the other months - which, in turn, showed no definite trends with DOPs in 2016 scoring higher yield on the average ( $\left.1.65 \pm 0.78 \mathrm{t} \mathrm{ha}^{-1}\right)$ than DOPs in 2017 (1.39 \pm $\left.0.68 \mathrm{t} \mathrm{ha}^{-1}\right)$. Combined analysis of both years confirmed higher average yield in March and a steady decline in 


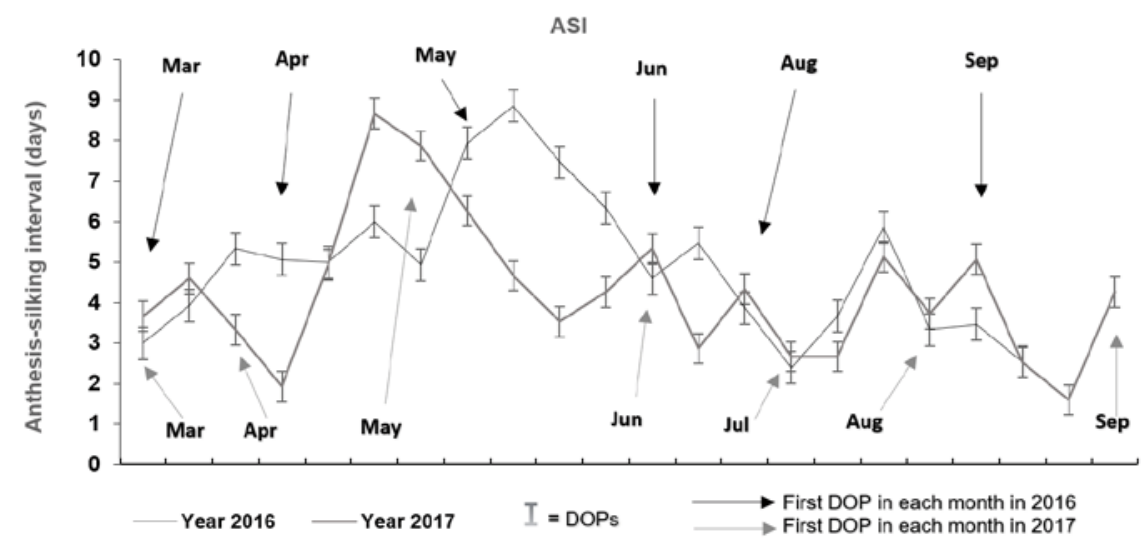

Figure 3: Mean values for the days from anthesis to silking of five maize varieties evaluated in 42 environments at the OAU T\&R Farm in 2016 and 2017 seasons.

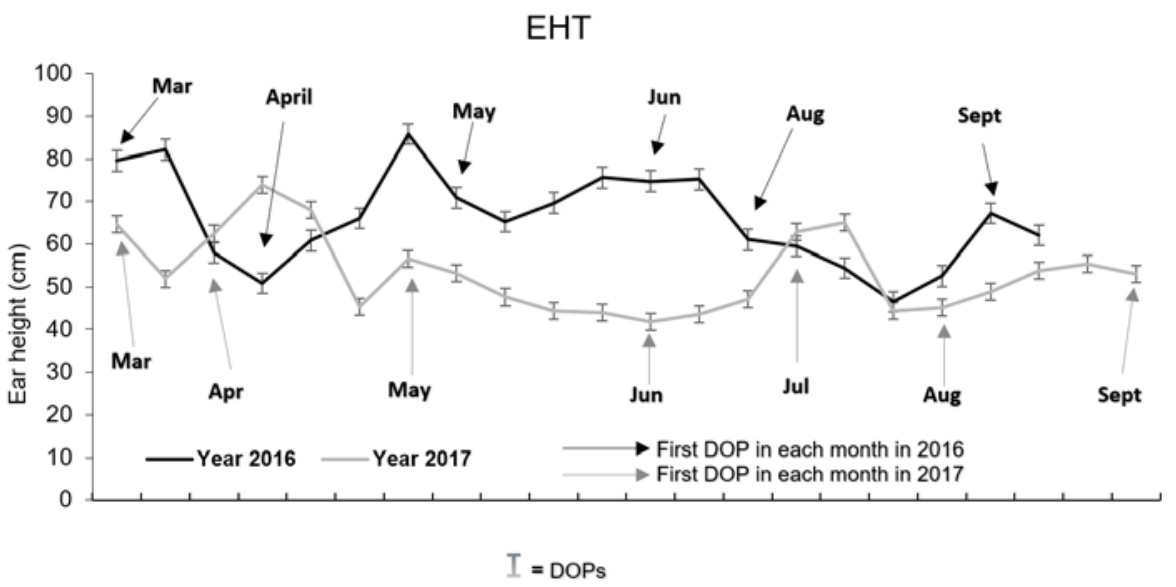

Figure 4: Mean values for ear height $(\mathrm{cm})$ of five maize varieties evaluated in 42 environments at the OAU T \& R Farm in 2016 and 2017 seasons.

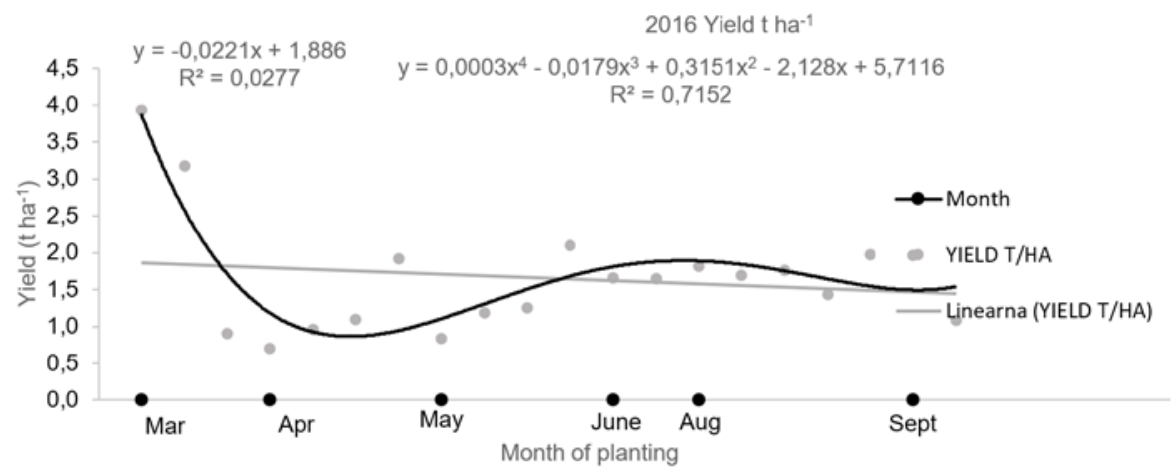

Figure 5: Mean grain yield ( $\left.\mathrm{t} \mathrm{ha}^{-1}\right)$ of five maize varieties evaluated over 20 DOPs at the OAU T\&R Farm in 2016 cropping season. 
subsequent months up until July when yield picked up declining again in September plantings (Figure 7).

Figures 5 and 6 indicate a somewhat linear decrease in yield with delays in planting, although the extremely low $\mathrm{R}^{2}$ values $(2016=2 \%, 2017=17 \%)$ especially for 2016 indicate that the linear yield response to DOP is almost certainly a decoy. The $\mathrm{R}^{2}$ values increased significantly $(2016=72 \%, 2017=62 \%)$ when cubic and especially quartic polynomials were plotted for the yield response to DOP with the high grain yield of the early DOPs in March of 2016 decreasing to the lowest level in April/May, and later increasing very slightly mid-season, and was somewhat uniform thereafter. In 2017, yield was highest in March/April, lowest mid-season, increased slighlty in late July/August before hitting another low in September. The $\mathrm{R}^{2}$ from the regression analysis of both years combined was at $45 \%$ when a cubic polynomial was plotted for yield in response to DOPs but the linear response of yield to DOPs was very low at $\mathrm{R}^{2}=5 \%$.

There were no correlations of seedling vigour traits with flowering and other adult plant traits including grain yield despite the fact that $\mathrm{E} \%$, PHT and EHT were all higher in 2016 than 2017 (Table 2). However, earlier flowering and shorter ASI as well as taller plants and higher ear placement increased yield significantly.

\section{DISCUSSION}

Results of this study decidedly reinforces the position that maize growth and productivity change in response to variation in planting date, as indicated by results of earlier studies (Fakorede, 1985; Oluwaranti et al., 2008) as well as common observations in farmers' fields. The present study, therefore, provides an additional sci-

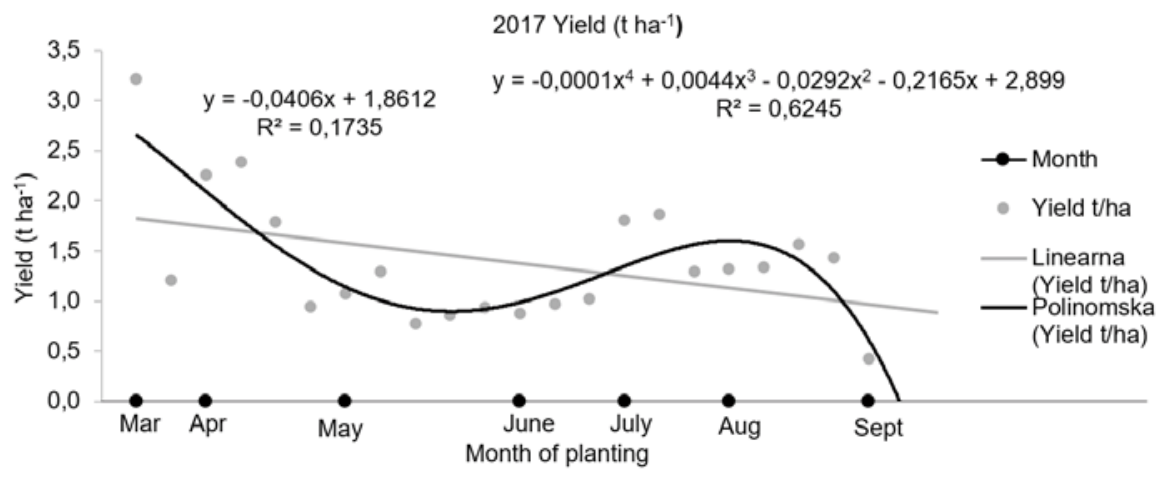

Figure 6: Mean grain yield ( $\mathrm{t} \mathrm{ha}^{-1}$ ) of five maize varieties evaluated over 22 DOPs at the OAU T\&R Farm in 2017 cropping seasons.

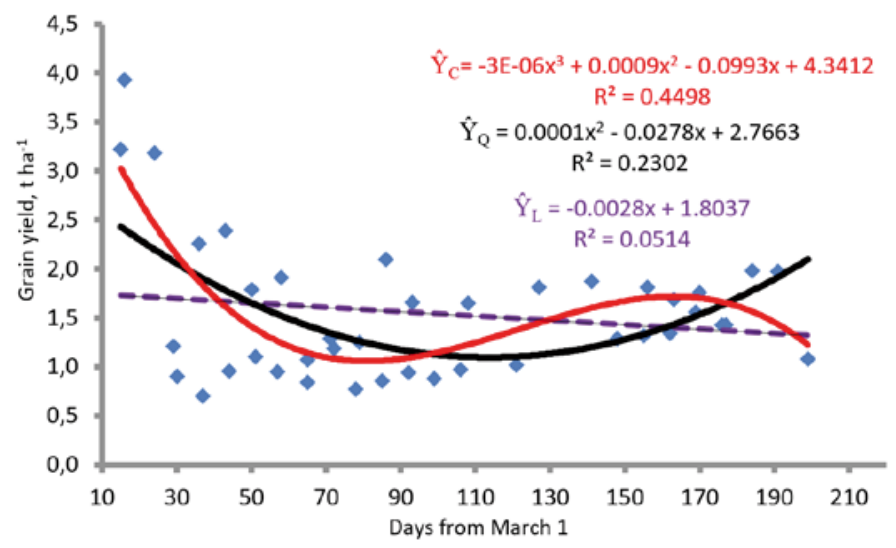

Figure 7: Mean grain yield $\left(\mathrm{t} \mathrm{ha}^{-1}\right)$ by DOPs of five maize varieties evaluated over 42 different planting dates at the OAU T\&R Farm in 2016 and 2017. 
Table 2: Correlation coefficients among agronomic traits and grain yield of five maize varieties planted over several environments at OAU T\&R Farm, Ile-Ife in 2016 and 2017 cropping seasons.

\begin{tabular}{|c|c|c|c|c|c|c|c|c|}
\hline & EI & $\begin{array}{l}\text { Days to } \\
\text { tassel }\end{array}$ & $\begin{array}{l}\text { Days to } \\
\text { anthesis }\end{array}$ & Days to silk & ASI, days & PHT, cm & $\begin{array}{l}\mathrm{EHT}, \\
\mathrm{cm}\end{array}$ & $\begin{array}{l}\text { YIELD, } \\
\text { t/ha }\end{array}$ \\
\hline E\%_9 & $-0.43^{\star \star}$ & -0.15 & -0.22 & -0.12 & 0.12 & 0.14 & 0.22 & 0.26 \\
\hline EI & & 0.18 & 0.28 & 0.11 & -0.23 & -0.10 & -0.23 & -0.10 \\
\hline Days to tassel & & & $0.98^{\star *}$ & $0.90^{* *}$ & 0.18 & $-0.50^{\star *}$ & $-0.58^{\star \star}$ & $-0.40^{\star \star}$ \\
\hline Days to anthesis & & & & $0.90^{\star *}$ & 0.12 & $-0.58^{* *}$ & $-0.67^{\star \star}$ & $-0.45^{\star *}$ \\
\hline Days to silk & & & & & $0.55^{\star *}$ & $-0.51^{* *}$ & $-0.56^{\star *}$ & $-0.54^{\star *}$ \\
\hline ASI, days & & & & & & -0.06 & 0.01 & $-0.37^{\star}$ \\
\hline PHT, cm & & & & & & & $0.92^{\star *}$ & $0.63^{* *}$ \\
\hline $\mathrm{EHT}, \mathrm{cm}$ & & & & & & & & $0.62^{\star *}$ \\
\hline
\end{tabular}

*, ${ }^{* *}$ Significantly different from zero at 0.05 and 0.01 level of probability, respectively.

entific proof the optimum DOP to maximize maize production in the rainforest agro-climatic zone of SW Nigeria is very early in the growing season. Highly significant mean squares were associated with the DOP source of variation for all traits at different growth stages, with the DOP sum of squares accounting for the largest proportion of the total sum of squares in each case, ranging from about $41 \%$ for E \% and EI to $59 \%$ for grain yield. Environmental conditions vary widely from day to day and from one environment to the other due to temporal and spatial variations in climatic factors such as temperature, precipitation, solar radiation, evapotranspiration, relative humidity, and edaphic factors relating to soil conditions. In this study, climatic factors varied widely among the environments (Fayose and Fakorede, 2021), probably aggravated by the impact of climate change which had been reported as affecting maize growth and production at the location (Fakorede and Akinyemiju, 2003). For instance, the "August break" normally distinct between early and late seasons at Ile-Ife, was not experienced in 2016 and there was a delay in the onset of rainfall in 2017 beyond what had previously been experienced at the location. These probably resulted in the large differences observed among the DOPs for most traits assayed in this study. For that reason, analysis of the data for the individual years separately was justified (Fig. 1).

Emergence is expected to be lower early in the season (because of low soil moisture) and later increase to an optimum mid-season before declining. This trend was more noticeable in 2016 as emergence in 2017 did not follow a discernible pattern. Also, flowering, PHT and EHT showed no particular trend from one DOP to another. Grain yield on the other hand, was significantly higher with the first few DOPs each year which might seem to support the results of the study by Fakorede (1985) who found that early planting ensured optimum maize grain yield and steady decrease in yield occurred with delays in planting. This makes sense because there is usually low cloud cover during the early DOPs thereby allowing optimum solar radiation, a necessary condition for maize optimum yield, to reach the surface. However, there were dates in March and April that performed very poorly in comparison to later DOPs which might seem to be contradictory to the findings of the aforementioned study. This, could be attributable to the relatively poor edaphic conditions probably resulting in inadvertently inadequate agronomic practices and the attack by army worm, Spodoptera frugiperda (Smith, 1797), which was a problem at a point during the study. Oluwaranti et al. (2008) observed similar results to those of Fakorede (1985) in the late season at the same location.

Analysis of the yield in the present study may have indicated no discernible trend in yield performance for both years under consideration. Beyond the early DOPs, however, a polynomial response (cubic) of yield to DOP was observed in which yield was highest very early in the season, dropping to its lowest value around mid-season before rising ever so slightly later and flattening out or somewhat decreasing afterwards. Further analysis of DOPs combined for both years showed a clear trend where average yield decreased steadily in each successive month till June and picked up in July/August before finally dropping off in September in what is clearly a cubic response of yield to DOPs. Year 2016 had higher emergence, earlier flowering, higher ear placement, and taller plants than 2017. This may be due to the higher amount of rainfall received during the growing season at the OAU T\&R Farm in 2016 (> $1000 \mathrm{~mm}$ ) compared to 2017 (675 mm). According to Fakorede and Agbana (1983) and Fayose and Fakorede (2014), varieties with high $\mathrm{E} \%$ and low values for EI and ERI tend to accumulate dry matter at a higher rate than slowly emerging 
varieties resulting in vigorous plants, thereby increasing yield directly or indirectly. This perhaps, is one of the reasons why yield was also higher in 2016 than 2017. Early flowering, short ASI, and taller plants were indeed associated with increased grain yield in this study even though seedling vigour had no significant relationship with yield. Seedling vigour could therefore be assumed to have influenced yield indirectly.

There was also significant DOP x Variety interaction for yield and other traits monitored in this study except PHT, indicating that the different maize varieties responded differently to the different climatic conditions. This suggests the tendency of certain varieties to perform better when planted in specific DOPs. Such varieties when planted in other DOPs outside their favoured DOP would struggle to reproduce the good performance. Each of the varieties indeed performed differently in one environment relative to others as indicated by the ANOVA. The hybrid, 'Oba Super 1' had the poorest average performance across DOPs on the one hand, whearas 'TZL Comp. 4 DT F ' and 'TZL Comp. 1 C6/DT - SYN - 1 - W' had the best average performances on the other hand. It would seem therefore that drought tolerant late maturing varieties would have better adaptation to this agro-ecology especially in the early season, which provides a window long enough for the partitioning of enough dry matter for the grain filling stage which, in turn, is extended to ensure higher grain return. However, the perfornance of 'White DT STR SYN1 - TZL Comp. 1 - W' was unlike the two varieties despite sharing similar characteristics, which casts a cloud on the earlier hypothesis. Nevertheless, 'TZL Comp. 1 C6/ DT - SYN - 1 - W' for its consistency across DOPs would seem the best of the varieties evaluated in this study for planting in the marginal rainforest agro-ecology of IleIfe in SW Nigeria. The gxe effect could be deeply investigated, however, with a larger sample size and that would give a larger degrees of freedom, allowing more room for comparison, with the goal of recommending the varieties that are best adapted to the rainforest agro-ecologies.

\section{CONCLUSIONS}

In conclusion, despite the prevailing climate change scenarios which has no doubt impacted agricultural activities especially crop production in the past few decades, this study established that planting maize early in the season ensures optimum grain yield. Yield decreased steadily as long as planting is delayed up till June. For optimum yield, planting should be done with the first few rains in March as long as soil moisture could be maintained either with supplementary irriagation or better soil management and other agronomic practices in case of the occurrence of drought of any duration, which is very probable with the present reality of climate change. Planting should not be delayed beyond early to mid April in the early season. Planting in the late season should be done around late July to mid-August. Planting beyond this period reduces yield and predisposes the plants to terminal drought.

\section{REFERENCES}

Badu-Apraku, B. and Fakorede M.A.B. (2017). Morphology and physiology of maize, p 33-53 In Advances in genetic enhancement of early and extra-early maize for sub-Saharan Africa, Springer International Publishing Company,Gewerbestrasse 11, 6330, Chan, Switzerland. https://doi.org/10.1007/978-3319-64852-1_3

Fakorede, M.A.B. (1985). Response of maize to planting dates in a tropical rainforest location. Experimental Agriculture, 21, 19-30.

Fakorede, M.A.B. and Agbana, S.B. (1983). Heterotic effects and association of seedling vigor with mature plant characteristics and grain yield in some tropical maize cultivars. Maydica, 28, 327-338. https://doi.org/10.1017/S0014479700012217

Fakorede, M.A.B. and Akinyemiju, O.A. (2003). Climate change: effects on maize production in a tropical rainforest location. P. 272-282. In Badu-Apraku, B., Fakorede, M.A.B., Ouedraogo, M., Carsky, R.J. and Menkir, A. (Eds.). Maize revolution in West and Central Afica. Proceedings of a Regional Maize Workshop, IITA-Cotonou, Benin Republic. 14-18 May 2001. WECAMAN/IITA.

Fayose, C.A. and Fakorede M.A.B. (2014). Growth analysis of maize varieties at the seedling and vegetative developmental stages. Proceedings of the Genetics Society of Nigeria Conference, Rubber Research Institute, Benin, Edo State, Nigeria, October 20-24. pp 425-429.

Fayose, C.A. and Fakorede M.A.B. (2021). Yield of maize in response to solar radiation in the tropical rainforest of sowthwestern Nigeria. Submitted to Field Crop Research.

Jibrin M. J., Kamara, A.Y. and Ekeleme, F. (2012). Simulating planting date and cultivar effects on dryland maize production using CERES-maize model. African Journal of Agricultural Research, 7(40), 5530-5536.

Jong, S.K., Brewbaker, J.L., and Chong, H.L. (1982). Effects of solar radiation on the performance of maize in 41 successive monthly plantings in Hawaii. Crop Science, 22, 13-18. https://doi.org/10.2135/cropsci1982.0011183X002200010004x

Oluwaranti, A., Fakorede, M.A.B. and Badu-Apraku, B. (2008). Grain yield of maize varieties at different maturity groups under marginal rainfall conditions. Journal of Agricultural Sciences, 58(8), 183 - 191. https://doi.org/10.2298/ JAS0803183O

SAS Institute Inc. (2000). “Base SAS 9.0 Procedures Guide." Cary, NC: SAS Institute Inc.

Talabi, A.O., Badu-Apraku, B. and Fakorede, M.A.B. (2017). Genetic variances and relationship among traits of an early maturing maize population under drought-stress and low nitrogen environments. Crop Science, 57, 681-692. https:// doi.org/10.2135/cropsci2016.03.0177 